\title{
Web-based Internship as a New Normal Learning Requirement for Accounting Students
}

\author{
Fitri Purnamasari ${ }^{1}$, Dhika Maha Putri ${ }^{2}$, Dwi Narullia ${ }^{3}$, Sheila Febriani Putri ${ }^{4}$, Mohd. Rizal \\ Palil ${ }^{5}$ \\ \{fitri.purnamasari.fe@um.ac.id ${ }^{1}$ \} \\ Universitas Negeri Malang, Indonesia ${ }^{1,2,3,4}$ \\ Universiti Kebangsaan Malaysia, Malaysia ${ }^{5}$
}

\begin{abstract}
The Covid-19 pandemic currently requires students and lecturers in various fields (including accounting) to adapt to the new normal life. This also has an impact on maximizing the use of technology as the main learning media, not least on internship activities by the students. Given the large contribution of the internship activities, the university should develop adequate facilities to maintain the process of supervision of the internship activities of the lecturers to the students they guide. Through the data we collected by surveys and in-depth interviews within accounting students who were taking part in internship activities in the Covid-19 pandemic era, this paper provides suggestions on design for platform websites as a medium for implementing technological-based internship. We believe that the website design that we are proposing will be appropriate for higher education institutions such as universities that are looking for the best solutions for internship activities for accounting students in new normal life.
\end{abstract}

Keywords: Learning Methods, Technology Usage, Accounting Students, New Normal Living, Covid-19 Pandemic

\section{Introduction}

As the Covid-19 disease is currently being spread around the world, various ways are being adopted to improve tracking, forecasting, and developing treatment methods to combat the pandemic. So far, the use of advanced technologies such as Machine Learning and Artificial Intelligence is also considered as one of the ways employed by various healthcare providers [1]. Not only in the health sector, the use of technology is also maximized to facilitate teaching and learning activities. This is also one of the impact of new normal life to break the spread of the Covid-19 pandemic.

The era of new normal life that is currently being promoted also requires the use of technology platforms that are more innovative and user-friendly. Nowadays, both students and lecturers in higher education levels are required to get used to use web-based platforms to share their knowledge, both during regular teaching and learning activities, or when they need to mentor the students who participate in internship programs. Previous studies by McManus \& Feinstein [2] and Clarke [3] have described that internship activities are media that can bridge students' abilities to be implemented in professional life, because internships can reflect various real experiences and integrate them for future use. Optimal internship activities, carried out in an active professional environment, and full of exploration in various forms of participating institutions, have proven to be a fundamental way to increase students' knowledge and skills, 
while helping them to gain insights on how the profession in their respective fields of science [4]. This demand certainly needs to be considered by higher education activists in the world today, including in Indonesia as a country that also needs to improve and prepare for the new normal era.

In Indonesia, it is revealed that with the existence of the Covid-19 pandemic this actually resulted in a variety of good practices that have been undertaken by teachers in conducting distance learning. Many teachers try to innovate and develop creativity. This is a form of how a teacher does things that are relevant to the situation of students but still enter the corridor of the subjects they teach [5]. For the 2020/2021 academic year which began in August, learning activities will be carried out while prioritizing the health and safety of all members of the higher education unit. For areas that are in the yellow, orange, and red zones the learning system continues with learning from home while for the green zone face to face learning can be done while still following the health protocol and the requirements set [6]. Matters that have been expressed by the ministry certainly also include student learning activities such as internship.

To realize the optimal internship activities amid the Covid-19 pandemic, we strive to provides suggestions on design for platform websites as a medium for implementing technological-based internship. Through the data we collected by surveys and in-depth interviews within accounting students who were taking part in internship activities in the Covid19 pandemic era, we put together a number of suggestions for designing websites as a facility for managing and overseeing internship activities at a higher education level. We are also developed our researches we have done before, which has built various suggestions for problem mapping of the internship activities of accounting students [7][8]. The website was chosen as the most effective media for students to carry out the reflection process during the internship period with their respective lecturers.

The reflection process that occurs when students examine their responses, beliefs, and premises-based on their experiences can gain new understanding [9]. Previous studies by Wells [10] have revealed that making written records, such as some reflective journals, can facilitate better reflection processes than face-to-face discussions. Students are also developed professionally by using reflective journals as learning media, because they can be able to link theories with practice and evaluate their work performance [11]. Therefore, we believe that the website design that we are proposing will be appropriate for higher education institutions such as universities that are looking for the best solutions for internship activities for accounting students in new normal life.

\section{Methods}

This research is a qualitative approach study that uses a case study design related to the implementation of internship in the accounting department. The research method is aimed at analyzing the need for technology utilization in internship practices. This analysis is carried out without treatment of the object of research, which is in line with the opinion of Creswell [12] qualitative researchers do not bring these individuals into the laboratory (or in situations that have been previously set); nor do they share instruments with them.

The data used in this study are primary data in the form of interviews and secondary data such as the accounting department's internship documents (SOPs, regulations and guidelines). The data in this study were collected through surveys in the form of "open-ended questions" in the middle of the year 2020, which were deepened through in-depth interviews thereafter. Research sources are stakeholders in internship activities: about ten students which are currently 
having "the new-normal internship system", four lecturers which are also the internship superintendence, and an operator/administrator of accounting internship program. Activities undertaken in data analysis are data reduction, data presentation, and drawing conclusions and data verification. After the data is analyzed, triangulation of sources is done by synchronizing the answers of informants (stakeholders related to internship).

\section{Result and Discussion}

As expressed in research of Putri et al. [8] internship is a medium to be able to optimize the work skills and mentality of students. With the internship program students are given the opportunity to learn both theory and practice to develop professional skills in college students [13]. When carrying out internship students will be able to compare and integrate the theoretical knowledge, they obtain in class with the practical conditions that occur in the world of work. Therefore, internship is an aspect that cannot be separated from its role to form students who are ready to work.

To facilitate the implementation of the internship to be able to provide maximum benefits for students, especially during the current pandemic, the role of technology is needed. With the advancement of modern technology, the use of the website provides a means for students to be able to continue to carry out the internship process to the full, provide guidance without having to face-to-face, and obtain the latest information in real time. This study aims to provide advice on website platform design as a medium for implementing internships.

\subsection{Problems that arise in the internship process during the pandemic}

During this pandemic, universities are required to hold all teaching and learning activities by continuing to implement social distancing, including in conducting internships. Therefore, with this new provision, problems arise in the process of implementing internship due to the limitations of students and other academic communities to be able to meet directly. The most common problem is the communication problem, which is related to unclear information and policies submitted by the university.

Based on the results of interviews with students, problems related to unclear and confusing information are the most felt by students. Following are some student statements that show student dissatisfaction about the publication of internship information.

"There are many mixed announcements circulating among students, many times a change of guidelines occurs, and announcements make students confused which one is correct" (IQ).

"The information conveyed by lecturer A is different from the information conveyed by lecturer $\mathrm{B}$, when asked to the university internship section, the answer is also unclear" (AG).

Based on a few excerpts from interviews with these students, the absence of clear information makes students confused about the implementation of internship. Furthermore because of the unclear information being conveyed, it results in unclear policies that often disadvantage students. 
"Initially, the policy said not to be allowed to carry out an internship at the company, this made us cancel the permit that had been submitted to the company. Then a few days later, the policy was changed which allowed for doing internship at companies by following the health protocol".

"We are disappointed with the policies issued by the university when it was still uncertain, because it caused us to have to repeatedly submit to third parties (companies) which made us, and the university look fickle".

"In a pandemic like this, the university does not seem to provide students the opportunity to carefully consider the options provided by the university. The administrative period and the implementation period of the internship were not extended even though the announcement of the changes to the internship scheme was only announced one week before".

It can be seen here that most students are not satisfied with the policies of the university. This could also be due to a delay in the delivery of policies from the center to units at the university so that students are also late in receiving information related to the policy. In the interview process, students also convey some suggestions to be able to make the university's internship system better.

"It is better not to announce the announcement before it is absolutely certain because it tends to be wishy-washy, universities should submit information to wait when it's completely clear" (DK).

"Maybe if there is a website, a live chat feature can be added for students so that information can be conveyed in real-time, especially when the department has not been synchronized with the center so students are free to ask questions on that platform" (RT).

"There should be a synchronization between the university's internship web internship and the web internship majors so there is no need to repeatedly register and the data be synchronized directly. In addition, links to agencies are also provided, but do not close the road if student want to doing internship in other agencies" (MT).

"Maybe the briefing regarding internships should be done two semesters before the implementation, so that there is plenty of time for students to prepare for internships" (HF).

\subsection{Platform that can provide solutions to internship problems during the pandemic}

From the problems raised in the previous section it can be concluded that there is a need for a platform that can bridge the limitations of direct meetings during the pandemic. One of the most popular technology platforms used in education, especially in distance learning, is the website [14][15]. The website here serves as a good alternative to replace face-to-face interaction, which goes beyond class and time constraints [16][17][18]. In this study we present 
a website design that can help maximize the implementation of internships for the better even during the pandemic. As said in the research of Chu, Chan and Tiwari [19] the web page is recommended as a suitable tool for the learning process during internship because of its associated uses in collaborative learning, reflection, communication, and social support.

Website is recommended as a useful tool for professional education or internship because this platform can be accessed anytime that allows user communities to interact and communicate with each other [20] in terms of internship including students and supervisors. During this pandemic, the website is a platform that can be said to be a bridge between users who are obstructed from the situation of not being able to meet in person. As expressed by students in the interview results above the internship website is expected to have a live chat feature that allows interaction between users quickly. Du and Wagner [21] say that websites allow simple and fast web content creation, frequent interactions with posts and comments, and instant hyperlinks to information sources. In addition, the website as an open system, also offers access to other applications in the external environment such as video-based software [for example, YouTube], image-based [Flickr], and bookmark-based, which effectively provides access to information wider. This feature will make it easier for students to get broader information, both initial guidelines, results and reporting guidelines can be presented in various forms of information to help students gain a comprehensive understanding from the beginning to the end of the internship.

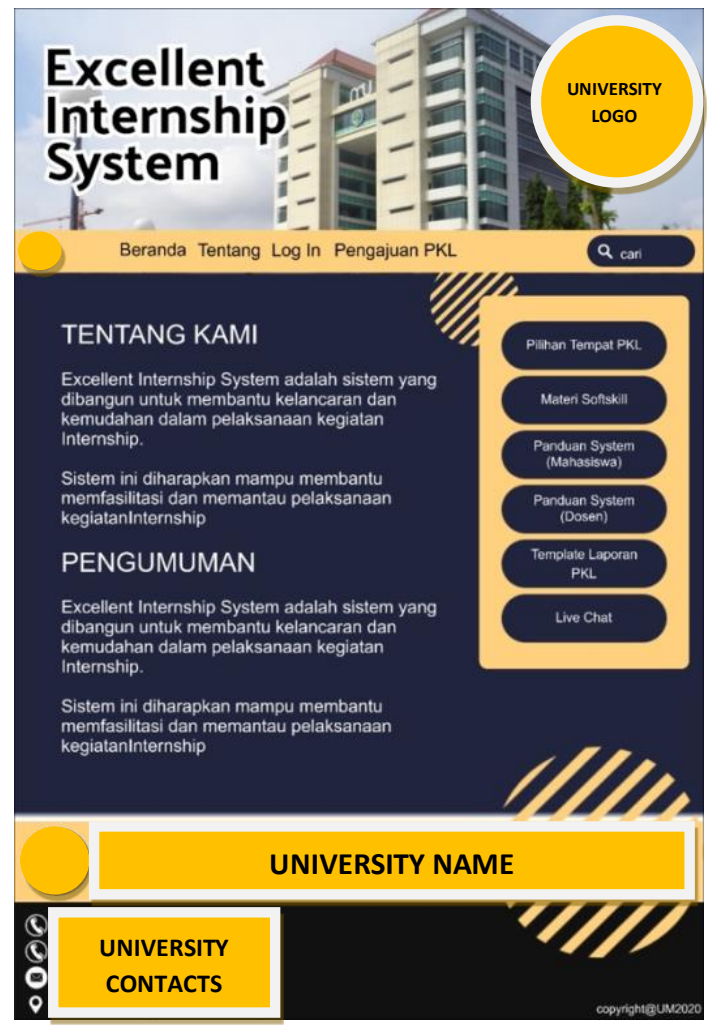

Fig. 1. Proposed Internship Website Design 
We offer a website platform that has the features needed by students to facilitate the internship process they are doing. The website features include:

1. Beranda

This feature is the main appearance of an Excellent Internship system website. This feature contains news and announcements related to internship activities.

2. Tentang

The "About" feature is a feature that contains a description of the website and the organizational structure of the internship manager in the accounting department.

3. $\log$ in

The "Log in" feature is a place where students register for an internship program online. After registering, students will get a username and password that can be used to access other features in this website.

4. Pengajuan PKL

In this feature, students can manage administrative matters related to internship activities, choose companies and obtain supervisors.

5. Pilihan Tempat PKL

This feature contains the list of companies that have collaborated with accounting major where the students may choose and apply their internship place.

6. Materi Softskill

"Materi Softskil" feature is a section that contains teaching materials related to soft skills. This material must be mastered by students during the internship process and can be consulted with their supervisor.

7. Panduan System (Mahasiswa)

This section contains guidelines for using the excellent internship system for students along with videos and tutorial modules. This feature is expected to facilitate students in operating the website.

8. Panduan System (Dosen)

This feature is a part that contains technical instructions for lecturers in utilizing excellent internship websites.

9. Template Laporan PKL

This feature contains the internship report format which can be downloaded by website users. The internship report will be uploaded at the end of the internship activity to be assessed by the lecturer.

10. Live Chat

This feature is used as a media to communicate synchronously between website users (lecturers, students, agencies and EIS website managers).

\section{Conclusion}

The Covid-19 pandemic currently requires students and lecturers in various fields (including accounting) to adapt to the new normal life. This also has an impact on maximizing the use of technology as the main learning media, not least on internship activities by the students. Given the large contribution of the internship activities, the university should develop adequate facilities to maintain the process of supervision of the internship activities of the lecturers to the students they guide. To facilitate the implementation of the internship to be able to provide maximum benefits for students, especially during the current pandemic, the role of technology is needed. With the advancement of modern technology, the use of the website 
provides a means for students to be able to continue to carry out the internship process to the full, provide guidance without having to face-to-face, and obtain the latest information in real time.

\section{References}

[1] S. Lalmuanawma, J. Hussain, and L. Chhakchhuak, "Applications of machine learning and artificial intelligence for Covid-19 (SARS-CoV-2) pandemic: A review," Chaos, Solitons \& Fractals, p. 110059, 2020.

[2] A. McManus and A. H. Feinstein, "Internships and occupational socialization: What are students learning?," in Developments in Business Simulation and Experiential Learning: Proceedings of the Annual ABSEL conference, 2008, vol. 35.

[3] M. Clarke, "Reflection: Journals and Reflective Questions: A Strategy for Professional Learning.," Aust. J. Teach. Educ., vol. 29, no. 2, p. n2, 2004.

[4] R. B. Weinberg, "The pre-doctoral psychology internship program at the University of South Florida/Florida Mental Health Institute.," Prof. Pract. Psychol., 1986.

[5] Kementerian Pendidikan dan Kebudayaan, "Kondisi Pandemi Covid-19 Mendorong Guru Berinovasi dalam Metode Pengajaran," Kementerian Pendidikan dan Kebudayaan, 2020. [Online]. Available: https://www.kemdikbud.go.id/main/blog/2020/06/kondisi-pandemicovid19-mendorong-guru-berinovasi-dalam-metode-pengajaran.

[6] Kementerian Pendidikan dan Kebudayaan, "Pembelajaran Pendidikan Tinggi dan Pendidikan Vokasi Utamakan Kesehatan dan Keselamatan," Kementerian Pendidikan dan Kebudayaan, 2020. [Online]. Available: https://www.kemdikbud.go.id/main/blog/2020/06/pembelajaranpendidikan-tinggi-dan-pendidikan-vokasi-utamakan-kesehatan-dan-keselamatan.

[7] F. Purnamasari, D. Narullia, D. M. Putri, F. Putri, S., and M. Puspaningtyas, "How The Excellent Internship Mentoring System Resolve Internship Student Problems?," in Book Chapter LPPM Universitas Negeri Malang, 2019.

[8] S. F. Putri, D. M. Putri, F. Purnamasari, M. P. Puspan-ingtyas, and D. Narullia, "Composing Professional Human Resource: The Necessity of Excellent Internship Mentoring System," KnE Soc. Sci., pp. 935-944, 2020.

[9] R. R. Rogers, "Reflection in higher education: A concept analysis," Innov. High. Educ., vol. 26, no. 1, pp. 37-57, 2001.

[10] G. Wells, Dialogic inquiry: Towards a socio-cultural practice and theory of education. Cambridge University Press, 1999.

[11] C. Sinclair and H. Woodward, "The impact of reflective journal writing on student teacher professional development," J. Int. Soc. Teach. Educ., vol. 1, no. 1, pp. 50-58, 1997.

[12] J. W. Creswell, Research Design: Pendekatan Metode Kualitatif, Kuantitatif, dan Campuran. Yogyakarta: Pustaka Pelajar, 2016.

[13] L.-J. ChanLin and W.-H. Hung, "Evaluation of an online internship journal system for interns," Procedia-Social Behav. Sci., vol. 191, pp. 1024-1027, 2015

[14] D. Churchill, "Educational applications of Web 2.0: Using blogs to support teaching and learning," Br. J. Educ. Technol., vol. 40, no. 1, pp. 179-183, 2009.

[15] S. Downes, "Educational blogging.," Educ. Rev., vol. 39, no. 5, pp. 14-21, 2004.

[16] M. L. Buffington, "Blogging with graduate students," Distance Learn., vol. 4, no. 1, p. 21, 2007.

[17] N. Ellison and Y. Wu, "Blogging in the classroom: A preliminary exploration of student attitudes and impact on comprehension," J. Educ. Multimed. Hypermedia, vol. 17, no. 1, pp. 99-122, 2008.

[18] S. Glogoff, "Instructional blogging: Promoting interactivity, student-centered learning, and peer input," Innov. J. Online Educ., vol. 1, no. 5, 2005.

[19] S. K. W. Chu, C. K. K. Chan, and A. F. Y. Tiwari, "Using blogs to support learning during internship," Comput. Educ., vol. 58, no. 3, pp. 989-1000, 2012.

[20] M. Levy, "WEB 2.0 implications on knowledge management," J. Knowl. Manag., 2009.

[21] H. S. Du and C. Wagner, "Weblog success: Exploring the role of technology," Int. J. Hum. Comput. Stud., vol. 64, no. 9, pp. 789-798, 2006. 